\title{
Effects of Hydrogen Peroxide on Dental Unit Biofilms and Treatment Water Contamination
}

\author{
Shih-Ming Lina \\ Kathy K.H. Svobodab \\ Anthony Gilettoc \\ Jeff Seibert ${ }^{d}$ \\ Raghunath Puttaiahe
}

\section{ABSTRACT}

Objectives: To study effects of various concentrations of hydrogen peroxide on mature waterline biofilms and in controlling planktonic (free-floating) organisms in simulated dental treatment water systems; and to study in vitro the effects of $2 \%, 3 \%$, and $7 \%$ hydrogen peroxide on the removal of mature biofilms and inorganic compounds in dental waterlines.

Methods: Four units of an automated dental unit water system simulation device was used for 12 weeks. All units were initially cleaned to control biofilms and inorganic deposits. $\mathrm{H}_{2} \mathrm{O}_{2}$ at concentrations of $1 \%, 2 \%, 3 \%$ was used weekly for periodic cleaning in three treatment group units lunits 1,2 \& 3), with $0.05 \%, 0.15 \%$ and $0.25 \% \mathrm{H}_{2} \mathrm{O}_{2}$ in municipal water used as irrigant respectively. The control unit (unit 4) did not have weekly cleanings and used municipal water as irrigant. Laser Scanning Confocal Microscopy and Scanning Electron Microscopy were used to study deposits on lines, and weekly heterotrophic plate counts done to study effluent water contamination. A 24 hour in vitro challenge test with $7 \%, 3 \%$ and $2 \% \mathrm{H}_{2} \mathrm{O}_{2}$ on mature biofilms was conducted using harvested waterlines to study biofilm and inorganic deposit removal.

Results: Heterotrophic plate counts of effluent water showed that the control unit reached contamination levels in excess of $400,000 \mathrm{CFU} / \mathrm{mL}$ while all treatment units showed contamination levels $<500 \mathrm{CFU} / \mathrm{mL}$ through most of the 12 weeks. All treatment units showed varying levels of biofilm and inorganic deposit control in this short 12 week study. The in vitro challenge test showed although there was biofilm control, there was no eradication even when $7 \% \mathrm{H}_{2} \mathrm{O}_{2}$ was used for 24 hours.

Conclusions: $2 \% \mathrm{H}_{2} \mathrm{O}_{2}$ used as a periodic cleaner, and diluted to $0.05 \%$ in municipal water for irrigation was beneficial in controlling biofilm and planktonic contamination in dental unit water systems. However, to remove well established biofilms, it may take more than 2 months when initial and multiple periodic cleanings are performed using $\mathrm{H}_{2} \mathrm{O}_{2}$. (Eur J Dent 2011;5:47-59)

Key words: Hydrogen peroxide; Biofilm; Dental units; Dental treatment water.

a Graduate student, Biomedical Sciences, TAMHSC Baylor College of Dentistry, Texas, USA.

b Co-PI \& Senior Scientist, Lynntech Inc., Texas, USA.

c Co-Investigator \& Vice Chair, Biomedical Sciences, TAMHSC Baylor College of Dentistry, Texas, USA.

d Dentist, Private practice, Texas, USA.

e Co-PI \& Research Mentor, Diagnostic Sciences, TAMHSC Baylor College of Dentistry, Texas, USA.
Corresponding author:

Raghunath Puttaiah

Associate Professor,

TAMHSC Baylor College of Dentistry,

3302 Gaston Ave,

Dallas, Texas 75246, USA.

E-mail: rputtaiahabcd.tamhsc.edu 


\section{INTRODUCTION}

Biofilms (organic contamination) are routinely found in dental treatment water delivery systems. ${ }^{1-8}$ They can be observed colonizing within dental unit waterlines in as little as two weeks. ${ }^{9}$ When viewed through a Scanning Electron Microscope (SEM), biofilms are characterized by microorganisms embedded in an extracellular matrix with thickness ranging from 30 to $50 \mathrm{mi}-$ crons that may allow chunks of material/biofilm to dislodge, thereby contaminating other areas of the dental treatment water system. ${ }^{10}$ Inorganic deposits (minerals) derived from dissolved salts in municipal water also contaminate the lines. ${ }^{11}$ These inorganic deposits are found interspersed with biofilms and are difficult to remove with most periodic cleaners/disinfectants. ${ }^{11,12}$ Colonization and proliferation of many and varied species of microorganisms has been well documented in dental unit water systems. ${ }^{13-20}$ Apart from bacteria, amoebae species have also been observed. ${ }^{21}$ Some of these microorganisms found in this environment have also been associated with hospital infections, and some in particular are of concern for the dental office. ${ }^{22-30}$ In one case, Mycobacterium xenopi was implicated in 19 cases of pulmonary disease in a hospital with transmission occurring through infected aerosols when patients used a shower. ${ }^{29}$ Water spray related aerosols generated by high-speed handpieces; ultrasonic/Piezo electric scalers and air/water syringes are common place in the dental environment contaminating the immediate surroundings of patients seated in the chair. ${ }^{31,32}$ These sprays and aerosols generated in the dental office could be a potential route for the transmission of microbes. ${ }^{18,32,33}$

Atlas et $a^{33}$ found Legionella in treatment water from dental units, water faucets and drinking water fountains. Aerosols generated by the dental handpieces were the source of sub-clinical infection with Legionella pneumophila in a dental school environment. ${ }^{18}$ Fotos et al ${ }^{34}$ investigated exposure of students and employees at a dental clinic and found that, of the 270 sera tested, $20 \%$ had significantly higher $\lg G$ antibody activity to the pooled $L e$ gionella sp. antigen as compared with known negative controls. In a similar sero-epidemiological study Reinthaler et $\mathrm{al}^{35}$ found a high prevalence of antibodies to Legionella pneumophila among dental personnel. These two cornerstone sero-epidemi- ological studies 34,35 on Legionella a known pathogen, are of significant concern to both dental care providers (occupational exposure), as well as iatrogenic disease risk to patients.

Other than microbes, very high doses of bacterial endotoxins (>100 EU/mL) were measured in dental unit water, with even municipal water containing more that $25 \mathrm{EU} / \mathrm{ML}^{36}$ Exposure of the patient to certain microbes associated with respiratory, enteric diseases or even conjunctivitis may be very plausible if the water quality is poor. ${ }^{37}$ The types of organisms may range from Amoebae, Legionella to $E$. coli ${ }^{21}$ seen in dental units connected to municipal water, or when connected to selfcontained reservoirs, which may be contaminated by the dental staff not following proper hand washing or aseptic procedures such as wearing gloves while handling self-contained reservoirs. ${ }^{37}$ Considering the presence of these contaminants, control methods for cleaning and disinfecting the dental water system and providing quality irrigant/ dental treatment water is warranted. To avoid water from passively dripping from the handpieces, air/water syringes, ultrasonic or Piezo electric scalers, devices are manufactured with a retraction mechanism. This mechanism can actively "suck-back" contaminants from the oral cavity with the introduction of oral contaminants including microbes into the dental unit waterlines and the dental unit water system. Today, many dental water systems (with retraction mechanisms) are equipped with anti-retraction values to prevent suck-back of contaminants from the oral cavity and/or are designed to give a short terminal flush' of water to push out any suck-back. ${ }^{38}$ In the in vitro experimental studies, even new and unused antiretraction valves were shown to be quite unreliable, leading to microbial suck-back into the waterline system from the patient end. ${ }^{39,40}$ Factors associated with biofilm formation in dental unit water systems could be-- long periods of stagnation, high surface to volume ratio, nutrient content of water for the microbial survival, mineral content and hardness of water facilitating coating of the lumen, fluid mechanics such as laminar flow, low flow rate, microbial quality (bacteria, fungi, protozoans and nematodes) of the water entering the system, and failure of anti-retraction valves leading to contamination from the oral cavity of patients. $37,39,40$ 
Flushing dental unit waterlines (DUWLs) with water at the beginning and end of patient treatment session have been previously advocated. .1,42 $^{4}$ This flushing protocol, as recommended earlier by the U.S. Department of Health and Human Services, ${ }^{43,44}$ may diminish planktonic organisms for a short period of time but will not eliminate contamination or control biofilms. One study concluded that a two minute flushing reduced the counts of planktonic organisms, on average by one-third, but did not reduce counts to zero. ${ }^{6}$ While it may provide transient reduction in planktonic microbes, purely flushing the water for a few minutes prior to treatment is not effective in biofilm control. ${ }^{21,45}$ Investigators have tested methods such as inline micro filter devices, ${ }^{7,8}$ flushing water lines with various disinfectant solutions which include hydrogen peroxide based chemicals, ${ }^{46,47}$ chlorhexidine gluconate, ${ }^{48,49}$ sodium hypochlorite, ${ }^{50-52}$ povidone-iodine, ${ }^{20}$ iodine, ${ }^{53}$ mouthwash, ${ }^{54}$ silver and silver compounds. ${ }^{55,56}$ Some of these periodic cleaning/disinfection methods, although effective in controlling planktonic organisms and possibly biofilms, do not eliminate existing biofilms or biofilm formation due to the inherent contamination of source water when municipal water or only low grade antimicrobials in the irrigant is used. Therefore in addition to initial \& periodic cleaning/disinfection of the water systems, purification of water or providing an irrigant of acceptable microbial quality is necessary. Using untreated tap/municipal source water for dental treatment is not reliable with respect to microbial quality, as studies have repeatedly demonstrated planktonic counts ranging from zero to at least a few hundred colony forming units, exceeding the contamination levels set per current CDC's recommendations for dental treatment water quality of 500 colony forming units/milliliter (CFU/mL) in the United States of America. $7,8,11,36,47,49,52,53,57,58$

Silver compounds and ionic silver have been used as antimicrobials in health care and particularly in dressing materials for burn care and wound care and have little or no side-effects but good antimicrobial properties. ${ }^{59-61}$ Silver citrate has been incorporated into the material composition of indwelling urinary catheters and has shown merits with respect to microbial and biofilm control.62,63 Silver ion technology (silver citrate) in municipal water as a continuously present antimicrobial is also being used to treat the municipal water for irrigation purposes. While use of sodium hypochlorite $(\mathrm{NaOCl})$ in higher concentrations is effective in biofilm control, 7,8,11,19 and in low concentrations in "improving" microbiological quality of dental treatment water, it is very corrosive and damaging to the dental unit water system. ${ }^{51,52}$ High amounts of trihalomethanes (carcinogens) are produced when in contact with organic matter such as biofilms. ${ }^{64}$ Constantly present low levels of $\mathrm{NaOCl}$ in the presence of organic matter can also increase the total trihalomethane levels beyond levels set by the U.S. Environmental Protection Agency. The use of $\mathrm{NaOCl}$ for the specified purpose of cleaning DUWLs has not been approved by the U.S. FDA. "Purely using any low level antimicrobial without initial and periodic cleaning of lines may expose patients and employees to endotoxins." 36

The objectives of this study were to determine the effects of various concentrations of hydrogen peroxide on mature waterline biofilms and in controlling planktonic (free-floating) organisms in simulated dental treatment water systems; an additional objective was to study in vitro the effects of $2 \%, 3 \%$, and $7 \%$ hydrogen peroxide on the removal of mature biofilms and inorganic compounds in dental waterlines.

\section{MATERIALS AND METHODS}

Naturally occurring biofilms of heterotrophic mesophilic microorganisms that had accumulated on dental lines utilized in dental suites were harvested and used in this study. No specific microbes were introduced into the lines. An automated, dental unit water system simulation device (Figure 1A-C.) was used to simulate the water flow in an operating dental suite. The simulation device was retrofitted with four dental unit waterlines lover 10 years old) to simulate water systems of four operating dental suites. The waterlines had mature biofilms and heterotrophic contamination of more than $400,000 \mathrm{CFU} / \mathrm{mL}$. Planktonic contamination was studied using heterotrophic plate counts and biofilm presence was confirmed using Laser Scanning Confocal Microscopy (LSCM) as well as Scanning Electron Microscopy (SEM). Effluent water was neutralized with sodium thiosulphate prior to heterotrophic plate count (HPC) in triplicate, to study contamination by planktonic microorganisms using R2A agar plates. R2A Agar 
growth medium is a low nutrient agar, which, in combination with a low incubation temperature and an extended incubation time, is suitable for the recovery of stressed and chlorine-tolerant bacteria from drinking water. ${ }^{65,66}$

The automated dental unit water simulation system prototype was initially designed, tested and used by Dr. R. Puttaiah, Mr. E. Gambal and Dr. S.E. Mills at the Dental Investigations Service, Brooks AFB, San Antonio, TX in 1995.7,8 The Automated Dental Unit Water System Simulator for in vitro use, used in this study was designed by Dr. R. Puttaiah, BCD TAMUS HSC, Dr. J. Zawada, A-dec Inc., and Dr. S. Seibert, BCD TAMUS HSC and constructed by A-dec Inc. Newberg, OR (Figure 1). The Simulation Device uses 8 dental unit water line systems built to scale which function as a dental unit water system. Each dental unit water line system simulates a single dental suite. Each Dental Unit has 4 handpiece lines and 1 Air/Water Syringe Line attached to a Control Block. The source water (inlet water) can be derived from the municipality or a self-contained reservoir (to introduce different irrigants). All 8 units can be independently controlled (independent unique functions) or may be collectively controlled using an Allen-Bradley Logic Controller (Allen-Bradley \& Rockwell Automation, Milwaukee, WI, USA) that turns the units 'on' and 'off' based on the algorithm provided to simulate water usage (period of flow) while manual valves control the flow volume. The algorithms have been programmed into the RSLogix (AllenBradley \& Rockwell Automation, Milwaukee, WI, USA) automation software using a personal computer, which in turn controls the logic controller based on programmed algorithms. The algorithms used in this study simulated typical dental clinic use of about $600-650 \mathrm{~mL}$ per day, with an intermittent flow (hourly cumulative time of 12 -minute random flow), 6 hour work day of 4 days per week. The unit was shut off nights and weekends.

Preparation of the test system

Waterlines from operating dental units 110 years or older) were harvested and attached to the Automated Dental Unit Water System Simulator. The Simulator used municipal water as irrigant for 1 month to maintain viable biofilms and heterotrophic contamination. Municipal water $\mathrm{pH}$ was 7.0 - 7.5 and the total dissolved solids 180 ppm to $250 \mathrm{ppm}$. Line samples were removed from each unit to evaluate the biofilm at baseline using LSCM (Figure 2). Heterotrophic Plate Count (HPC) of planktonic or free-floating microbes in effluent treatment water samples were collected from each unit to measure contamination levels. HPC of effluent water showed a maximum contamination of $>400,000 \mathrm{CFU} / \mathrm{mL}$ from the collected water in each dental unit.

To study effects of Hydrogen Peroxide $\left(\mathrm{H}_{2} \mathrm{O}_{2}\right)$ on mature waterline biofilms and in controlling planktonic organisms in dental treatment water, four units in the simulated dental water system were used in this study.

- Unit 1 (treatment 1) used $1 \% \mathrm{H}_{2} \mathrm{O}_{2}$ for 4 initial cleanings each 5 minutes in contact within the lumen followed by weekly cleaning. Irrigant was $0.05 \% \mathrm{H}_{2} \mathrm{O}_{2}$ in municipal water for simulated dental care.

- Unit 2 (treatment 2) used $2 \% \mathrm{H}_{2} \mathrm{O}_{2}$ for 4 initial cleanings each 5 minutes in contact within the lumen followed by weekly cleaning. Irrigant was $0.15 \% \mathrm{H}_{2} \mathrm{O}_{2}$ in municipal water for simulated dental care.

- Unit 3 (treatment 3) used $3 \% \mathrm{H}_{2} \mathrm{O}_{2}$ for 4 initial cleanings each 5 minutes in contact within the lumen followed by weekly cleaning. Irrigant was $0.25 \% \mathrm{H}_{2} \mathrm{O}_{2}$ in municipal water for simulated dental care.

- Unit 4 (control) was initially cleaned using 60 ppm of Active Chlorine Dioxide $\left(\mathrm{ClO}_{2}\right) 4$ times for 5 minutes contact and used municipal water as an irrigant for simulated dental care. No additional cleaning with $\mathrm{ClO}_{2}$ was conducted throughout the rest of the study.

Baseline and weekly water samples were collected in sterile containers. The lines hold approximately $20 \mathrm{~mL}$ water; therefore, $10 \mathrm{~mL}$ water was collected before use in the morning after the unit remained stagnant overnight. These were pooled samples $(4$ handpiece and 1 Air/Water Syringe lines from each simulation unit) of about 2 $\mathrm{mL}$ each. All the external line surfaces near the effluent area ( 6 inches) of the tubing were cleaned with an alcohol swab twice before collection to control external contamination. The collected water was neutralized with sodium thiosulphate by mixing $0.1 \mathrm{~mL}$ water sample in $0.9 \mathrm{~mL}$ sodium thiosulphate $110 \mathrm{mg}$ in $125 \mathrm{~mL}$ sterile water, Millipore Whirl-pak bag with thiosulphate) and held 
for 30 seconds. A $1.0 \mathrm{~mL}$ aliquot of the neutralized sample was plated on R2A agar, incubated at room temperature $\left(22^{\circ} \mathrm{C}\right)$ for 7 days and the colonies counted. Water samples were plated in triplicate. Sterility controls were conducted in parallel. Mean heterotrophic CFUs/mL were converted into $\log _{10}$ values (CFUs/mL) for normalization of data and compared using Oneway Analysis of Variance and Scheffe's post-hoc test at alpha 0.05.

LSCM of biofilms and other deposits in the lumen of lines were studied on the lumenal surfaces from lines, with $1 \mathrm{~cm}$ from each unit harvested at baseline (post initial cleaning) and at 60 days. The outer surface of the waterline to be harvested was wiped with an alcohol swab on the outside and handled aseptically. The blade used to slice the line was wiped clean with an alcohol swab. A $1 \mathrm{~cm}$ section of line from each Unit was removed, slit axially and immediately dyed using the Molecular Probes, Invitrogen Corporation, Carlsbad,

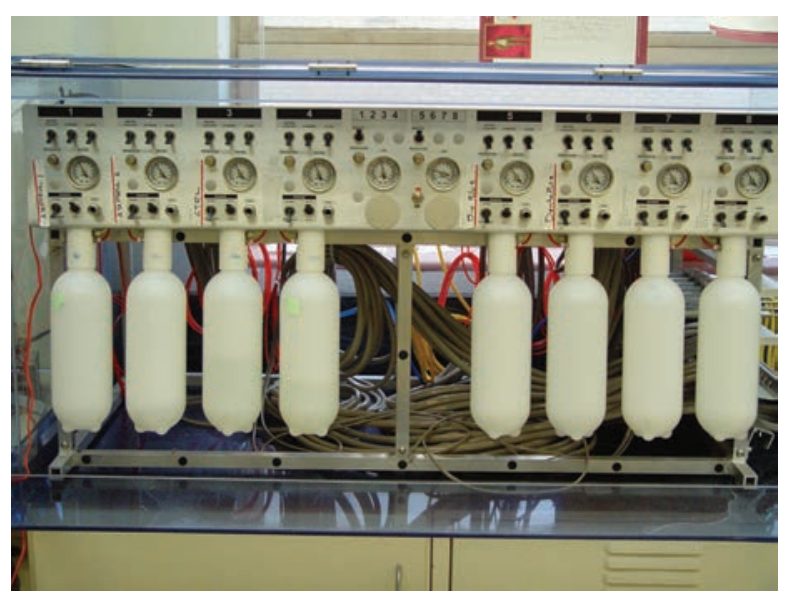

Figure 1A. Front view of the automated dental unit simulator showing 8 dental unit water systems with pressure gauges and manual control switches.

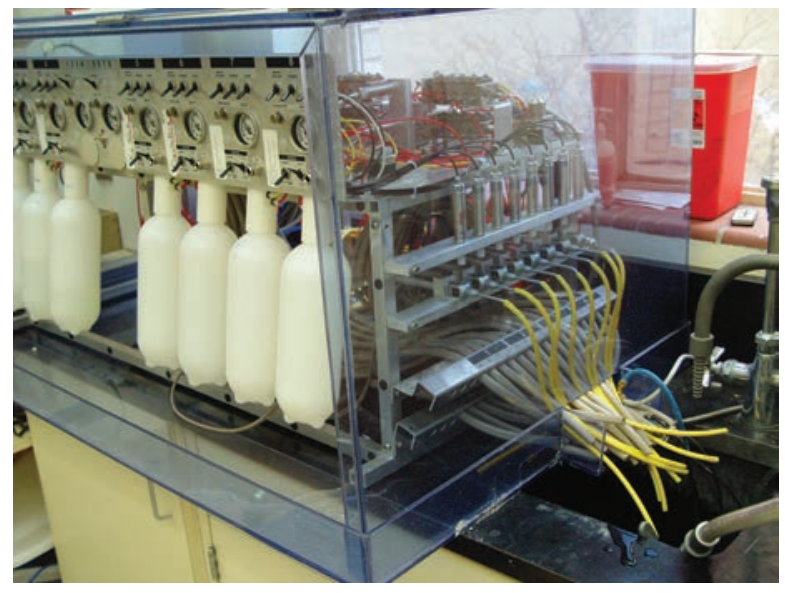

Figure 1B. Side view showing effluent end of waterlines $/ 4$ handpiece \& 1 Air/Water Syringe per each of the 8 dental unit water systems) and pneumatic controls.
California, USA. LIVE/DEAD ${ }^{\circledR}$ Bac Light ${ }^{\mathrm{TM}}$ Assay (The BacLight Green (B-35000) and BacLight Red (B-35001) bacterial stains are fluorescent labeling reagents for detecting and monitoring bacteria. These two dyes are not nucleic acid stains. Bacteria stained with the BacLight Green and BacLight Red bacterial stains exhibit bright green and red fluorescence labsorption/emission $\sim 480 / 516$ and $\sim 581 / 644 \mathrm{~nm}$, respectively. The BacLight kits are well suited for use with LSCM. The LIVE/DEAD BacLight Bacterial Viability Kits employ two nucleic acid stains - the green-fluorescent SYTO ${ }^{\circledR}$ 9 stain and the red-fluorescent propidium iodide stain. These stains differ in their ability to penetrate healthy bacterial cells. When used alone, SYTO 9 stain labels both live and dead bacteria. In contrast, propidium iodide penetrates only bacteria with damaged membranes, reducing SYTO 9 fluorescence when both dyes are present. Thus, live bacteria with intact membranes fluoresce green, while dead bacteria with damaged membranes fluoresce red). While being observed using laser scanning confocal microscopy, the sample holding mount/immersion slide was wiped with an alcohol swab and sterile water was used for immersion. No neutralization of the biofilm samples was conducted. Following staining, the lines were immediately studied using LSCM. The biofilms were observed using a water immersion 40X lens and digital images made.

The complete lumenal surface was scrutinized and the worst case scenario recorded/imaged to identify any residual biofilm or other deposits. Although topographic images and channel graphs

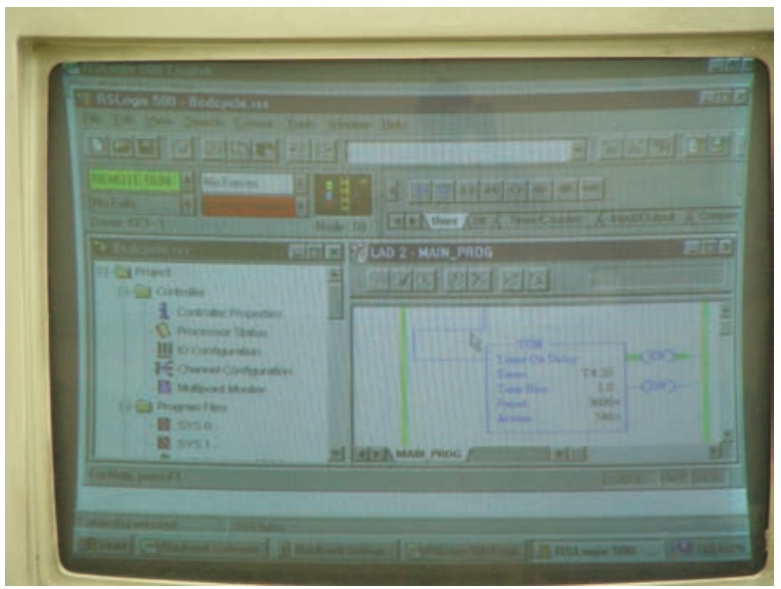

Figure 1C. Computer Terminal Screen displaying a unique algorithm/flowchart on "RS Logix Automation Software" that controls Allen-Bradley Logic Controller, and the latter controlling the "opening and closing" functions of water in the Handpiece lines and the Air/Water Syringe lines. 
including quantitative outputs were generated, no quantitative tests or three-dimensional analysis were performed on the output as we did not standardize the view, field or aperture for the images as needed for quantification. ${ }^{67}$ Only live/ dead (green/red) images were used for qualitative presence or absence of viable biofilm/cells. After LSCM the same samples were desiccated, coated with gold palladium for SEM and the worst case scenario (maximum contamination in sample) viewed and recorded/imaged at 1600X. SEM was conducted to see if there were biofilms but mostly for studying inorganic matter such as salt deposits from hardness in municipal water previously used in the lines when they were in use in clinical

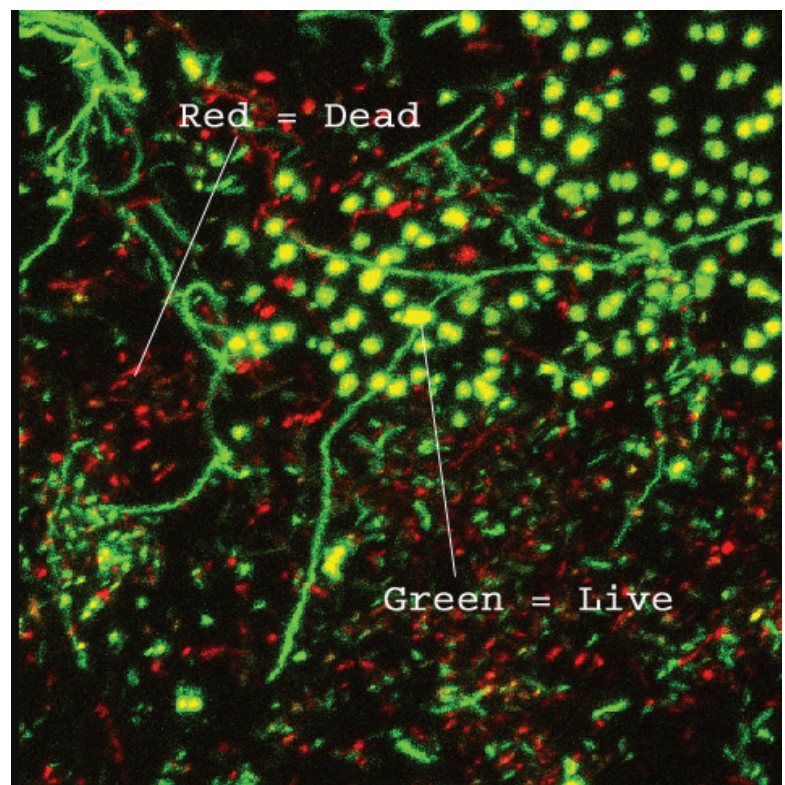

Figure 2. Laser Scanning Confocal Micrograph of a mature dental unit waterline biofilm showing Green and Red dyed cells (dyed with Baclight ${ }^{T M}$ Green and Red). The Green cells are "Live" cells (absorb Green Dye) and the Red cells are "Dead" cells (absorb Red Dye) in the biofilm. These cells are interspersed within the biofilm along with the extracellular components. dental units.

To study the effects of $2 \%, 3 \%$ and $7 \% \mathrm{H}_{2} \mathrm{O}_{2}$ on mature biofilms and inorganic compounds in dental waterlines, three $250 \mathrm{~mL}$ monojet syringes were attached to lines (30 cm long) with about 10 -14 year old biofilms. Treatment Group 1 used 2\% $\mathrm{H}_{2} \mathrm{O}_{2}$, Treatment Group 2 used $3 \% \mathrm{H}_{2} \mathrm{O}_{2}$, and Treatment Group 2 used $7 \% \mathrm{H}_{2} \mathrm{O}_{2}$ to challenge biofilms and inorganic matter in lines. For each group, a fresh $10 \mathrm{~mL}$ of $\mathrm{H}_{2} \mathrm{O}_{2}$ of their respective concentration was loaded at $0,5,10,20,30,60,180,360$ and 1440 minutes. There were no active flushes between loadings at each time interval. A line sample (1 cm length) at each time interval was gently harvested from each group (distal end away from the syringe) for LSCM (procedures for processing line samples were similar to those in Task 1) and SEM to study removal of both inorganic and deposits. The luminal surface was scrutinized to identify the worst case scenario for both biofilm and inorganic deposits and imaged. A representative sample was not taken or considered as we wanted to identify any residue. Outcomes were classified on a 5 level ordinal scale for biofilm/deposit presence with $1=$ presence of mature biofilm matrix; 2=biofilm present \& no mature matrix; $3=$ scattered microbes \& no biofilm; $4=$ no microbes $\&$ no biofilms; $5=$ inorganic deposits with no biofilm or microbes.

\section{RESULTS}

Figure 3 shows the graph of longitudinal observation of the contamination levels (HPC) of the effluent water from the control and the treatment units and were computed as CFUs/mL. After initial cleaning of all the units (Treatment and Control Units), all effluent counts started below the $500 \mathrm{CFU} / \mathrm{mL}$ maximum contamination level

Table 1. Descriptive statistics of heterotrophic contamination in effluent water from simulated control and treatment units.

\begin{tabular}{|c|c|c|c|}
\hline Unit & & Mean & Std. Deviation \\
\hline \multirow{2}{*}{ Control Unit } & Absolute CFU/mL & 104365.65 & 101773.21 \\
\hline & $\log _{10} \mathrm{CFU} / \mathrm{mL}$ & 4.73 & 0.62 \\
\hline \multirow{2}{*}{ TX Unit 1} & Absolute CFU/mL & 13.48 & 60.35 \\
\hline & $\log _{10}$ value & 1.49 & 0.84 \\
\hline \multirow{2}{*}{ TX Unit 2} & Absolute CFU/mL & 1.74 & 3.88 \\
\hline & $\log _{10}$ value & 1.00 & 0.00 \\
\hline \multirow{2}{*}{ TX Unit 3} & Absolute value & 1.30 & 3.44 \\
\hline & Absolute CFU/mL & 1.00 & 0.00 \\
\hline
\end{tabular}


of treatment water set by the CDC. The control unit showed unacceptable levels from week 1 onwards reaching a maximum contamination level of $400,000 \mathrm{CFU} / \mathrm{mL}$ by the end of the 12 week study. Treatment Unit 1 showed a maximum contamination in week 2 and thereafter remained below 500 $\mathrm{CFU} / \mathrm{mL}$. Treatment Units 2 \& 3 remained below $500 \mathrm{CFU} / \mathrm{mL}$ limit throughout the 12 week study.

A summary of descriptive statistics (Table 1) addresses the mean contamination levels (both absolute values and $\log _{10}$ values of the $\mathrm{CFUs} / \mathrm{mL}$ ). One way analysis of variance $(\alpha=0.05)$ and Scheffe's post hoc tests were used to study any difference between the $\log _{10}$ values of the effluent heterotrophic plate counts of the four units. Test for homogeneity of variance showed a significant difference between the contamination levels among the groups $(P<.05)$. Scheffe's post hoc test for multiple comparisons determined that there was no significant difference between any of the treatment groups $(P>.05)$, while all treatment groups showed significantly lower contamination levels than the control group $(P<.05)$.

LSCM and SEM of the waterline surfaces to study the effects of periodic cleaning with $\mathrm{H}_{2} \mathrm{O}_{2}$ and the use of dilute $\mathrm{H}_{2} \mathrm{O}_{2}$ as irrigant in differing concentrations conducted in Task 1 are described as a template (Figure 4). At baseline, the Control Unit had a minimal amount of salt deposits and biofilms while the Treatment Unit 1 had a clean line surface with no visible salt or biofilm deposits in the field of view Treatment Units 2 and 3 showed very little biofilm deposits but a significant amount of salt deposits at baseline. At the end of the study, both the Control Unit and the Treatment Unit 1 showed residual biofilms. Treatment Units 2 and 3 showed cleaner line surfaces with respect to salt deposits but still showed residual biofilm. All Z-view samples (Control \& Treatment Groups) showed residual biofilm deposits ranging from traces to a large mass. In this 12 week study, only the $3 \%$ and $2 \% \mathrm{H}_{2} \mathrm{O}_{2}$ showed better salt removal than the $1 \% \mathrm{H}_{2} \mathrm{O}_{2}$.

The in vitro test (Task 2) to study the effects of 2,3 and $7 \% \mathrm{H}_{2} \mathrm{O}_{2}$ on biofilm removal were a 24 hour longitudinal challenge study. All three groups had biofilms and salts at baseline. $2 \% \mathrm{H}_{2} \mathrm{O}_{2}$ periodic cleaner/disinfectant had a minimal noticeable disruption of the mature biofilm with some removal of inorganic deposits. $3 \% \mathrm{H}_{2} \mathrm{O}_{2}$ showed a noticeable removal of biofilm and salt deposits. $7 \% \mathrm{H}_{2} \mathrm{O}_{2}$ removed biofilm and salt deposits similar to the $3 \% \mathrm{H}_{2} \mathrm{O}_{2}$. Although minimal, there still remained some residual biofilm on the line surface in both the $3 \%$ and $7 \% \mathrm{H}_{2} \mathrm{O}_{2}$ treatments (Figure 5).

\section{DISCUSSION}

Contamination of dental unit water systems and possibility of risks to patients have been addressed for over 50 years. ${ }^{15,16}$ Although the American Den-

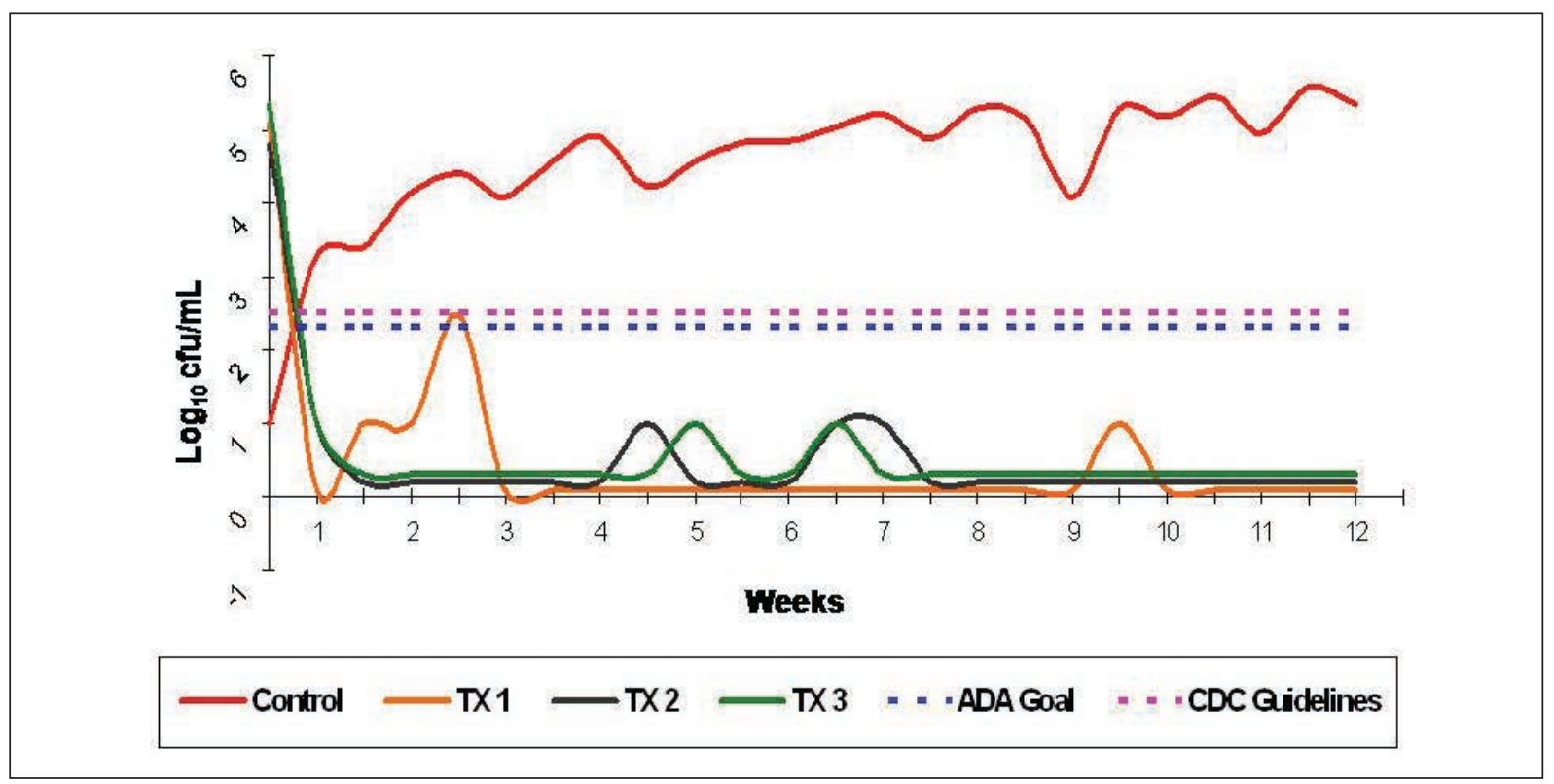

Figure 3. The Control Unit's contamination started at $<10 \mathrm{CFU} / \mathrm{mL}$ reached unacceptable contamination levels by the end of the first week. Although all Treatment Units were highly contaminated prior to initial cleaning, their counts remained below $500 \mathrm{CFU} / \mathrm{mL}$ throughout the study period but for one sample from Treatment Unit 1. Treatment Unit 1 showed only one count of $>500 \mathrm{CFU} / \mathrm{mL}$ in week 3 but remained below $500 \mathrm{CFU} / \mathrm{mL}$ for the remainder of the 12 week study. 
tal Association (ADA) set goals of $<200 \mathrm{CFU} / \mathrm{mL}$ of heterotrophic counts for dental treatment water contamination levels, only in the recent past, the ADA and the Centers for Disease Control \& Prevention concluded that the maximum contamination of dental treatment water should be $<500$ $\mathrm{CFU} / \mathrm{mL}$ and that biofilms in dental unit water sys- tems should be controlled. ${ }^{44,68,69}$ These guidelines are based on microbial characteristics, patient susceptibility, lack of and difficulties associated with epidemiological surveillance (morbidity and mortalityl other than sero-epidemiological studies demonstrating health risks for both patients and employees. $4,5,14,18,21,31-36,68,69$

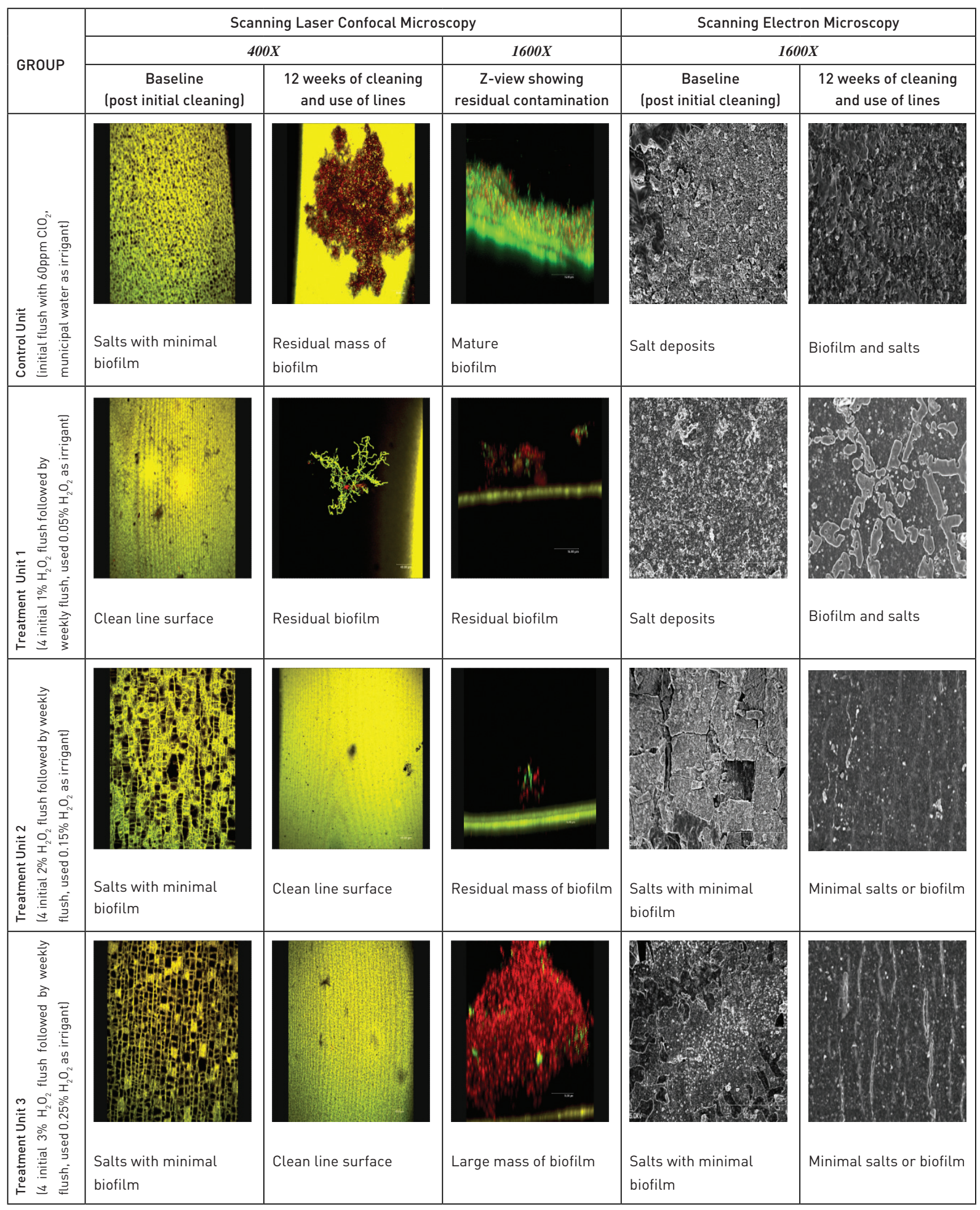

Figure 4. Laser scanning confocal \& scanning electron micrographs of baseline and post study waterline surfaces - in vivo 12 week study. 
Hydrogen peroxide in different formulations lalkaline peroxide as well as silver added to $6 \%$ $\mathrm{H}_{2} \mathrm{O}_{2}$ respectivelyl has been studied with respect to biofilm control in dental unit water systems. ${ }^{56,70,71}$ In this study we used over the counter hydrogen peroxide that was readily available in pharmacies, for both periodic cleaning as well as a low grade irrigant after dilution in municipal water, and hydrogen peroxide that was marketed as a high-level disinfectant (Sporox, Sultan Chemicals, NY) as periodic flush only. The main thrust of this study was to determine in vitro lbut as close as possible to use in dental equipment) the best concentration of $\mathrm{H}_{2} \mathrm{O}_{2}$ for periodic cleaning of already existing deposits (both inorganic and biofilms) in dental unit water systems. In addition we wanted to determine a much lower and safer concentration of $\mathrm{H}_{2} \mathrm{O}_{2}$ in municipal water as irrigant/coolant for use in dental treatment. After determining periodic cleaning and the irrigant concentrations, the prototype fuel-cell technology based $\mathrm{H}_{2} \mathrm{O}_{2}$ electrochemical generator could be calibrated to produce the concentrations on a turn-key basis.

The prototype fuel cell based $\mathrm{H}_{2} \mathrm{O}_{2}$ generator that was developed and calibrated has demonstrated the capability to produce up to $3.3 \% \mathrm{H}_{2} \mathrm{O}_{2}$ for greater than 4000 hours of use lbased on testing of the prototype at Lynntech Inc. College Station, Texas, USA). Other than the biofilm challenge tests and control of microbial contamination of the dental water system, effects of $\mathrm{H}_{2} \mathrm{O}_{2}$ on metal and non-metal components of the water system,

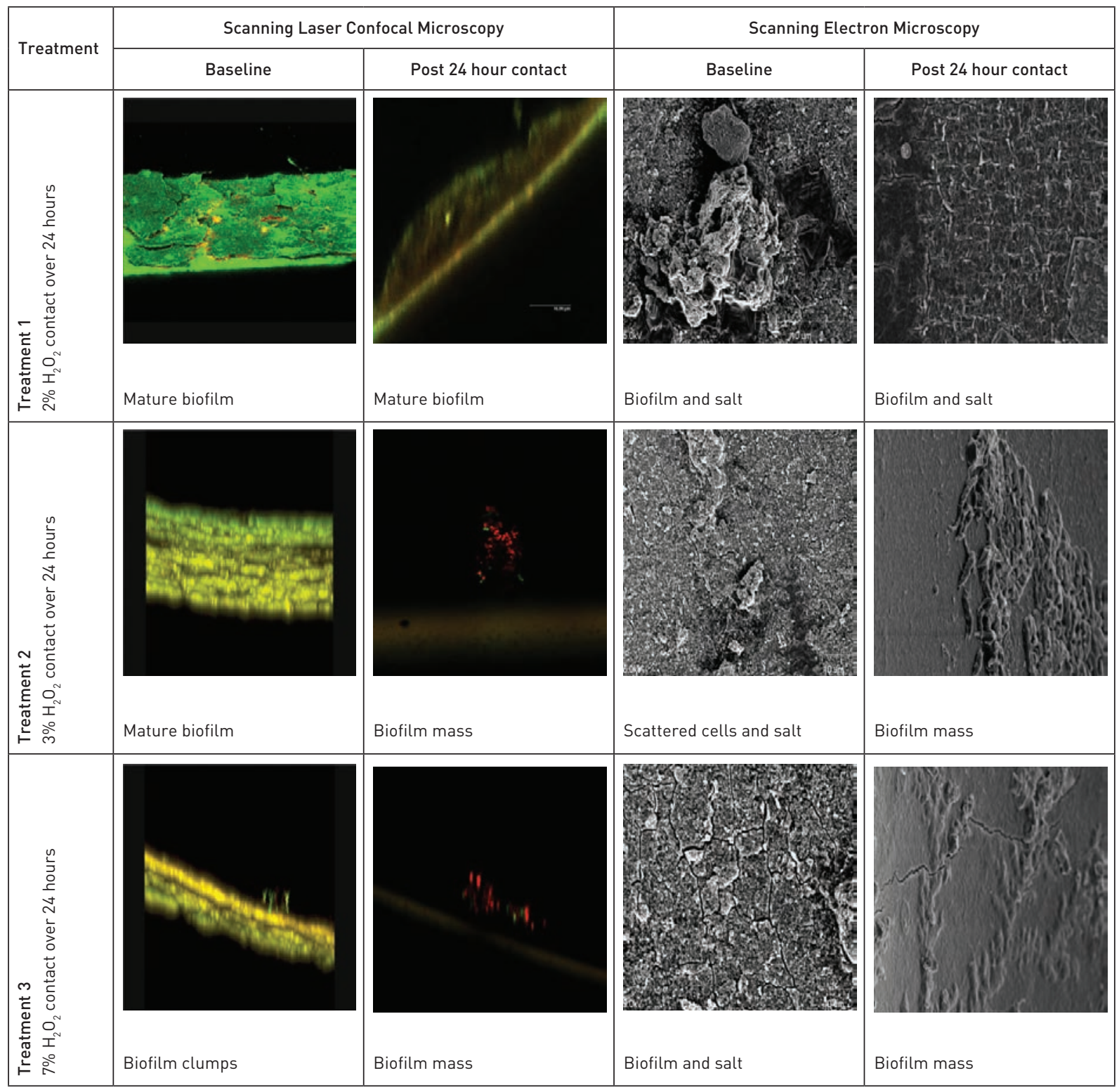

Figure 5. Laser scanning confocal and scanning electron micrographs of baseline and post 24 hour challenge waterline surfaces - in vitro 24 challenge test. 
elemental metal analysis using standardized metal coupons, and effects on composite bonding to enamel and dentin were also studied and will be published in series or in other suitable journals. These types of tests need to be performed not only for efficacy testing of germicides in microbial control, but also to determine deleterious effects if any, on dental unit water systems as well as patient safety. The information generated could be used by regulatory agencies such as the United States Environmental Protection Agency (US-EPA) for disinfectant/device registration, and the United States Food and Drug Administration (US-FDA) in providing marketing clearance of the physical device as well as the electrochemically produced germicide for efficacy as well as for patient safety respectively.

$\mathrm{H}_{2} \mathrm{O}_{2}$ and $\mathrm{ClO}_{2}$ were chosen as germicides of choice in this study due to safe history in mouthwash and as a solution to decontaminate items used in patient care. They are relatively less harmful than sodium hypochlorite and do not produce disinfection-by-products such as trihalomethanes in the presence of organic matter. ${ }^{12,36,47,49,53,64}$ In this study, lines with naturally grown biofilms attached to an automated in vitro system were used to study effects of the germicide $\left(\mathrm{H}_{2} \mathrm{O}_{2}\right)$. Naturally grown biofilms interspersed with salts from hard water cannot be standardized and are hardier than rapidly grown biofilms without salt deposits developed in a laboratory. ${ }^{72}$ Natural biofilms in dental waterlines as observed in this study was found interspersed with salt deposits. One of the issues was that the salts may have had a neutralizing/buffering effect on inorganic chemicals $\left(\mathrm{H}_{2} \mathrm{O}_{2}\right)$ used as a biofilm control agent as observed in this study.

We proposed that contamination control in dental unit water systems should be a combination approach, addressing biofilm removal/control as well as the control of planktonic microbes that contribute to contamination of dental irrigant/ coolant. This combination approach will be helpful in meeting the CDC Guidelines of $<500$ CFU $/ \mathrm{mL}$ in dental treatment water from dental units and ultrasonic units for general dental treatment on a consistent basis. This approach of multiple baseline decontamination followed by scheduled periodic treatment of the system to control biofilms and inorganic components demonstrated control of planktonic microbes in dental treatment water (Table 1, Figure 3) as within 3 weeks all treatment groups showed mean counts of $<10 \mathrm{CFU} / \mathrm{mL}$. The control group that was initially cleaned but used municipal water had contamination levels exceeding the $500 \mathrm{CFU} / \mathrm{mL}$ mark by the second week and reached $>400,000 \mathrm{CFU} / \mathrm{mL}$ by week 12 . In contrast, biofilm eradication within 12 weeks was not accomplished (Figure 4). When concentrations as high as $3 \%$ were used for initial and periodic cleaning, the representative scans showed no biofilm or salt deposits by the end of study, however, on further scrutiny of the complete line surface, we found occasional clumps of residual biofilm. Biofilm disruption and control was seen in all treatment units with varying degrees. In the in vitro biofilm challenge test (Figure 5), $7 \% \mathrm{H}_{2} \mathrm{O}_{2}$ (very high concentration) did not eradicate biofilms in the waterline, even when in contact with the line surface for 24 hours, demonstrating the tenacity of naturally occurring deposits (inorganic salts and biofilms) in dental waterlines. $7 \% \mathrm{H}_{2} \mathrm{O}_{2}$ however should not be used for cleaning lines as it is very corrosive on dental unit water system components leven $1 \%$ $\mathrm{H}_{2} \mathrm{O}_{2}$ showed some corrosion over time). One possible explanation for not being able to eradicate biofilms could be buffering effects of the salts lining the surface of the waterlines on the $\mathrm{H}_{2} \mathrm{O}_{2}$ being introduced and weaken its effects on biofilms. More standardized studies need to be conducted to study this phenomenon. Biofilm eradication was difficult and even the control of biofilms could take a long time in older dental units that have never been cleaned before. Multiple initial cleanings followed by weekly cleanings with $\mathrm{H}_{2} \mathrm{O}_{2}$ as low as $1 \%$ and use of resulting $0.05 \% \mathrm{H}_{2} \mathrm{O}_{2}$ in municipal water regularly as an irrigant controlled biofilms and planktonic contamination of the dental waterlines and treatment water respectively. After reviewing outcomes of various concentrations of $\mathrm{H}_{2} \mathrm{O}_{2}$ on dental unit water system components, standardized metal coupons, composite bonding to enamel and dentin (completed in the broader study ${ }^{12}$ that will be published separately), we determined that $2 \% \mathrm{H}_{2} \mathrm{O}_{2}$ when used as a periodic cleaner $<<5$ minute contact with lines), and $0.05 \%$ mixture in municipal water for irrigation purposes was effective in controlling biofilms and planktonic contamination. 


\section{CONCLUSIONS}

Based on the findings in this study, we conclude that $2 \% \mathrm{H}_{2} \mathrm{O}_{2}$ used as a periodic cleaner, and diluted to $0.05 \%$ in municipal water for irrigation, was beneficial in controlling biofilm and planktonic contamination in dental unit water systems and met the CDC's guidelines of $<500 \mathrm{CFU} / \mathrm{mL}$ of heterotrophic microorganisms in dental treatment water. However, to remove well established biofilms, it may take more than 2 months when multiple initial cleanings and repeated weekly cleaning with $2 \% \mathrm{H}_{2} \mathrm{O}_{2}$ are conducted.

\section{ACKNOWLEDGEMENTS}

This study was funded by the National Institutes of Health - National Institute of Dental \& Craniofacial Research, Small Business Innovative Research Phase II Grant \# 2R43DE14280-01, Subcontract from Lynntech Inc. to Baylor College of Dentistry, Texas A\&M University Health Science Center, through the Texas A\&M University Research Foundation.

\section{REFERENCES}

1. Peters E, McGaw W. Dental unit water contamination. J Can Dent Assoc 1996;62:492-495

2. Barbeau J. Multiparametric analysis of waterline contamination in dental units. J Can Dent Assoc 2000;66:539-541.

3. Williams HN, Kelly J, Folineo D. Assessing microbial contamination in clean water dental units and compliance with disinfection protocol. J Am Dent Assoc 1994;125:1205-1211.

4. Putnins EE, Di Giovanni D, Bhullar AS. Dental unit waterline contamination and its possible implications during periodontal surgery. J Periodontol 2001;72:393-400.

5. Fayle SA, Pollard MA: Decontamination of dental unit water system: a review of current recommendations. Br Dent $J$ 1999;181:369-372.

6. Williams JF, Johnston AM, Johnson B, Huntington MK, Mackenzie CD. Microbial contamination of dental unit water-lines: prevalence, intensity and microbiological characteristics. J Am Dent Assoc 1993;124:59-65.

7. Puttaiah R, Mills SE. Longitudinal pilot study of the efficacy of different treatments on dental unit water systems. 1995 Conference on Pharmaceutical Science and Technology, in Conjunction with the 26 Annual Meeting of the Fine Particle Society. 08/26/1995, Chicago, IL.

8. Puttaiah R, Mills SE, Plamondon TJ, Thrash WJ, Cottone JA. A multi-group longitudinal study of dental unit waterline contamination. J Dent Res 1996:75: 414.
9. Scarbeck K. Dental unit waterlines - curbing infectious midstream. AGD Impact 1993:21:6-12.

10. Lizotte JR, Peters E, Whitehouse R. Influence of biofilms on microbial contamination in dental unit water. $J$ Dent $1991 ; 19: 290-295$

11. Kim PJ, Cederberg RA, Puttaiah R. A pilot study of 2 methods for control of dental unit biofilms. Quintessence Int 2000;31:41-48.

12. Puttaiah R, Lin S, Giletto A, Svoboda KKH. Efficacy of $H 202$ in controlling dental unit water system contamination. Abstract \# 0639, AADR 2006 Annual Scientific Session, Orlando, Florida, USA. (http://iadr.confex.com/iadr/20060rld/ techprogram/abstract_76738.htm)

13. Sawyer DR, Page DG, Sweeney W, Dalton HP. Bacterial contamination and disinfection of the dental handpiece and the water it delivers. Virginia Dent J 1976;53:14-23.

14. Fitzgibbon EJ, Bartzokas CA, Martin MV, Gibson MF, Graham R. The source, frequency and extent of bacterial contamination of dental unit water systems. Brit Dent $J$ 1984;157:98-101.

15. Neff JH, Rosenthal SL. A possible means of inadvertent transmission of infection to dental patients. J Dent Res 1957;36:932-934.

16. Blake GC. The incidence and control of bacterial infection in dental spray reservoirs. Brit Dent $J$ 1963;115:413-416.

17. Moriarty JD, Crawford JJ. Evaluation of an independent sterile water reservoir system for highspeed instrumentation. J Dent Res 1976;55: B275.

18. Oppenheim BA, Sefton AM, Gill ON, et al. Widespread Legionella pneumophila contamination of dental stations in a dental school without apparent human infection. Epidemiol Infect 1987;99:159-166.

19. Pankhurst CL, Philpott-Howard JN, Hewitt JH, Casewell MW. The efficacy of chlorination and filtration in control and eradication of Legionella from dental chair water systems. J Hosp Infect 1990;16:9-18.

20. Mills SE, Lauderdale PW, Mayhew RB. Reduction of microbial contamination in dental units with povidone-iodine 10\%. J Am Dent Assoc 1986;113:280-284.

21. Barbeau J, Buhler T. Biofilms augment the number of free-living amoebae in dental unit waterlines. Res Microbiol 2001;152:753-760.

22. Speller DCE, Stephens ME, Viant AC. Hospital infection by Pseudomonas cepacia. Letters to the editor. Lancet $1971 ; 17: 798$.

23. Sorrell WB, White LV. Acute bacterial endocarditis caused by a variant of the genus. Herrella Amer J Clin Path $1953 ; 23: 134$. 
24. Basset DCJ, Stokes KJ, Thomas WRC. Wound infection with Pseudomonas multivaorans a water-borne contamination of disinfectant solutions, Letters to the editor. Lancet 1970;6:1188.

25. Speller DCE. Colonization of dental units by water bacteria. Brit Dent $J$ 1973;135:189-190.

26. Schiff J, Suter LS, Gourley RD. Flavobacterium as a cause of bacterial endocarditis. Ann of Intern Med 1961;55:499506.

27. Lowry PW, Beck-Sague CM, Bland LA, et al. Mycobacterium chelonae infection among patients receiving high-flux dialysis in a hemodialysis clinic in California. J Infect Dis 1990;161:85-90.

28. Weinberger M, Berg SL, Feuerstein IM, Pizzo PA, Witebsky FG. Disseminated infection with Mycobacterium gordonae: report of a case and critical review of the literature. Clin Infect Dis 1992;14:1229-1239.

29. Costrini AM, Mahler DA, Gross WM, et al. Clinical roentgenographic features of nosocomial pulmonary disease due to Mycobacterium xenopi. Am Rev Resp Dis 1981;123:104-109.

30. Lowry PW, Jarvis WR, Oberle AD, et al: Mycobacterium chelonae causing otitis media in an ear-nose-and-throat practice. N Engl J Med 1988;319:978-982.

31. Miller RL, Micik RE, Abel C, Ryge G. Studies on dental aerobiology: II. Microbial splatter discharged from the oral cavity of dental patients. J Dent Res 1971;50:621-625.

32. Bentley CD, Burkhart NW, Crawford JJ. Evaluating spatter and aerosol contamination during dental procedures. J Am Dent Assoc 1994;125:579-584.

33. Atlas RM, Williams JF, Huntington MK. Legionella contamination of dental-unit waters. Appl and Environ Microbiol 1995;61:1208-1213.

34. Fotos PG, Westfall HN, Snyder IS, Miller RW, Mutchler BM. Prevalence of Legionella-specific $\lg G$ and $\lg M$ antibody in a dental clinic population. J Dent Res 1985;64:1382-1385.

35. Reinthaler FF, Mascher F, Stunzner D. Serological examination for antibodies against Legionella species in dental personnel. J Dent Res 1988;67:942-943.

36. Puttaiah R, Cederberg RA. Assessment of endotoxins in dental unit treatment water. J Dent Res 1998;77:263.

37. Puttaiah R, Mills SE. Research model addressing policy issues for the dental unit water system. 1995 Conference on Pharmaceutical Science and Technology, in Conjunction with the 26 Annual Meeting of the Fine Particle Society. 08/26/1995, Chicago, IL.

38. Fayle SA, Pollard MA. Decontamination of dental unit water systems: A review of current recommendations. Brit Dent $J$ $1996 ; 181: 369-72$
39. Montebgnoli L, Dolci G. A. Effectiveness of two devices designed to prevent fluid retraction in a high-speed handpiece. J Prosthet Dent 2000;84:225-228.

40. Berlutti F, Testarelli L, Vaia F, De Luca M, Dolci G. Efficacy of anti-retraction devices in preventing bacterial contamination of dental unit water lines. J Dent 2003;31:105-110.

41. Samaranayke LP, Scheutz F, Cottone J. Infection control for the dental team. Copenhagen Munksgaard 1991:98-99.

42. Samaranayke LP. Handpiece and water-line decontamination and HIV transmission: A critique. Dent Update 1993;20:53-56.

43. US Department of Health and Human Services, Centers for Disease Control and Prevention: Recommended Infection Control Practices for Dentistry. MMWR 1993, 42:No. RR-8.

44. US Department of Health and Human Services, Centers for Disease Control and Prevention: Guidelines for Infection Control in Dental Health-Care Settings. MMWR 2003, 52:No. RR-17.

45. Karpay RI, Puttaiah R, Mills SE et al. Efficacy of flushing dental units for different time periods. J Dent Res 1997;76:434.

46. Kellet M, Hobrook WP. Bacterial contamination of dental handpieces. J Dent 1980;8:249-253.

47. Puttaiah R, Shafer T, Svoboda KKH, Spears R, Heaton M, Lin S, Thomas AC. Evaluation of hydrogen peroxide for dental unit waterline contamination control. Abstract \# 1070, AADR 2003 Annual Scientific Session, San Antonio, Texas, USA.

48. Blake GC. The incidence and control of bacterial infection in dental spray reservoirs. Brit Dent J 1963;115:413-420.

49. Puttaiah E, Cederberg RA, Sargent C, Spears R, Powers D. Efficacy of a CHG irrigant in biofilm and planktonic contamination of dental unit water systems. Abstract \# 665, IADR 2000 Annual Scientific Session, Washington DC. Special Issue Vol: 79, p 227.

50. Abel IC, Miller RL, et al. Studies on dental aerobiology: IV. Bacterial contamination of water delivered by dental units. J Dent Res 1971;50:1567-1569.

51. Plamondon TJ, Mills SE, Sherman LR, Nemeth J, Puttaiah R. Effect of bleach on mature biofilm in dental unit waterlines. J Dent Res 1996;75:414.

52. Puttaiah R, Karpay RI, Fabre C, Sherman LR, Nemeth JF, Mills SE, Plamondon TJ. Dental unit waterline treatment with sodium hypochlorite and acetic acid. Microchemical Journal 1998;59:333-340.

53. Puttaiah R, Siebert J, Cederberg R, Spears R. Effects of constantly present low-grade iodine on dental unit waterline biofilm and planktonic contamination. Abstract presented at the OSAP Annual Scientific Session, June, 1999, Cincinnati $\mathrm{OH}$, USA. 
54. Meiller T, Baqui A, DePaola L, Overholser CD. Disinfection of dental unit water lines using Listerine antiseptic. J Dent Res 1995;74:153.

55. Meiller TF, Kelley JI, Zhang M, DePaola LG. Efficacy of Adec's ICX dental unit waterline treatment solution in the prevention and treatment of microbial contamination in dental units. J Clin Dent 2004;15:17-22.

56. Puttaiah R, Lin S, Lumsden J. Evaluation of a silver citrate dental water decontaminating agent. March 2006, Abstract \#0638, AADR, Orlando, Florida, USA. (http://iadr.confex. com/iadr/20060rld/techprogram/abstract_76640.htm]

57. Puttaiah R, Waggoner MB, Sherman LE, Bryan WR, Kim PJ. Efficacy of citric acid in controlling biofilms in dental unit waterlines. J Dent Res 1998;77:851.

58. Puttaiah R, Cederberg R, Wneck R. Efficacy of chlorhexidine in controlling biofilm contamination of dental unit waterlines. J Dent Res 1998; 77:262.

59. Brett DW. A discussion of silver as an antimicrobial agent: alleviating the confusion. Ostomy Wound Manage 2006;52:34-41.

60. Schaller M, Laude J, Bodewaldt H, Hamm G, Korting HC. Toxicity and antimicrobial activity of a hydrocolloid dressing containing silver particles in an ex vivo model of cutaneous infection. Kin Pharmacol Physiol 2004;17:31-36.

61. Lansdown AB, Williams A, Chandler S, Benfield S. Silver absorption and antibacterial efficacy of silver dressings. $J$ Wound Care 2005;14:155-160.

62. Hashimoto H, Ono N, Monden K, Kumon H, Shiba T, Adachi T, Kaneko K. Basic study on anti-bacterial urethral catheter. II. Potency of a new anti-bacterial catheter and its durability in experimental models. The Journal of the Japanese Association of Infectious Diseases (Kansenshogaku Zasshi) 2000;74:441-449.

63. Hashimoto $H$. Evaluation of the anti-biofilm effect of a new anti-bacterial silver citrate/lecithin coating in an in-vitro experimental system using a modified Robbins device. The Journal of the Japanese Association of Infectious Diseases (Kansenshogaku Zasshi) 2001;75:678-685.

64. Puttaiah R, Siebert J, Chen P. Release of disinfection-byproducts during $\mathrm{NaOCl}$ use on contaminated dental unit water systems. Annual Meeting of the Organization for Safety and Asepsis Procedures, Providence, RI, abstract \#9807; June 18-21, 1998.

65. Reasoner DJ, Geldreich EE. A new medium for enumeration and subculture of bacteria from potable water. Appl Environ Microbiol 1985;49:1-7.

66. American Water Works Association's "Standard Methods for Examination of Water and Wastewater", 20 2 th Edition. 1998.
67. de Carvalho CCCR, da Fonseca MR. Assessment of threedimensional biofilm structure using an optical microscope. Biotechniques 2007;42:616-620.

68. Shearer BG. Biofilm and the dental office. J Am Dent Assoc 1996;127:181-189.

69. ADA Council of Scientific Affairs. Dental unit waterlines: Approaching the year 2000. J Am Dent Assoc 1999;130:16531664.

70. Linger JB, Molinari JA, Forbes WC, Farthing CF, Winget WJ. Evaluation of a hydrogen peroxide disinfectant for dental unit waterlines. J Am Dent Assoc 2001;132:1287-1291.

71. Szymanska J. Antifungal efficacy of hydrogen peroxide in dental unit waterline disinfection. Ann Agric Environ Med 2006;13:313-317.

72. Charaf UK. A model biofilm for efficacy assessment of antimicrobials (publication number - WO/2000/077162). World Intellectual Property Organization, International Bureau (http://www.wipo.int/pctdb/images4/PCT-PAGES/2000/512000/00077162/00077162.pdf). 